\title{
An Empirical Analysis of Predictor Influence \\ Mechanisms of HRM Practices and Corporate Sustainability on Employee Engagement: A Mediation
}

\author{
Analysis \\ Georgia Rosemarie Simon \\ Department of Management \\ Huazhong University of Science \& Technology, China \\ Erhua (Iris) Zhou \\ Department of Management \\ Huazhong University of Science \& Technology, China
}

\section{Gideon Sagoe}

School of Environmental Studies, China University of Geosciences (Wuhan), China

Received: March 13, 2018 Accepted: April 4, 2018 Online published: April 10, 2018

doi:10.5296/ijhrs.v8i2.12811 URL: https://doi.org/10.5296/ijhrs.v8i2.12811

\begin{abstract}
The unquestionable benefits of employee engagement and the ill-effects of disengagement (EE) have necessitated further investigation within the field of human resource management and the wider organizational studies domain. This study sought to measure the perception of employees at a Commercial Bank in Jamaica, on how various practices in the organization, such as human resource management practices (HRMPs), the ethical climate (OEC), and corporate sustainability (CS) affected their engagement. Based on the responses of 130 employees who responded to a self-administered questionnaire hosted online, it was shown quantitatively that employee tenure in an organization affects their engagement, as employees with less than one year, and more than ten years of service with the organization were more engaged. Also, the results indicated that both HRMPs and initiatives and strategies on CS had influence on employees' behaviour and subsequently their engagement and the predictor effects were enhanced by the mediation effect of OEC. These findings are relevant to practice
\end{abstract}


as well as provide elucidation on the specific mechanisms that influence the relationship between HRMPs and EE, as well as contributing to sparse literature on EE in a Caribbean context.

Keywords: HRM practices, rewards and compensation, training and development, organizational ethical climate, corporate sustainability, employee engagement, mediation analysis

\section{Introduction}

Over the past two decades, organizations have experienced unprecedented changes within the business landscape which has created an interesting opportunity for researchers and practitioners of organizational studies. The widespread changes brought on by various global socio-economic causalities resulting from successive recessions, globalization, changing labour force and advanced technology has had both positive and negative impact on industries and the labour force. The outcome of these changes has presented a significant challenge for business leaders and particularly Human Resource Management in developing strategies that would keep employees challenged, empowered, motivated and to find meaningfulness on their jobs. In this current era of constant change, significant pressure has been placed on organizations to assert their strategic efforts in order to gain competitive advantage, and to stay relevant in business. Consequently, the work of the Human Resource Department has become more challenging, as the consequences of employee engagement the changes in the labour market has a profound influence on the HR practices (Wollard \& Shuck, 2011).

In light of these changes and challenges the internal organizations nowadays have to be more assertive with cutting edge practices. The rapid competitive environments, requires fast adaptation as competitors are able to quickly imitate the products and services of their competitors in order to gain competitive advantage and market share. The financial industry, of which this study investigated, thrives on competition. Among the challenges of the industry, their biggest challenge is to create a work environment that facilitates employee engagement and sustain competitive advantage. Accordingly, survivability within these competitive environments, require the innovativeness of a robust human resource (HR) strategy, as the concept of EE has implications to all areas of HR practice, and achieving positive organizational outcomes which may generate sustainable competitive advantage (Wollard \& Shuck, 2011).

Owing to this, understanding the concept of employee engagement (EE) has become a worldwide phenomenon among leaders as the high cost of disengagement poses a threat to business sustainability and competitive advantage. Studies have shown that disengagement costs American firms in excess of 400 billion dollars per year (Sorenson, 2013). The alarming global status on the state of engagement has created more awareness and urgency among industry and academia as the findings reveal that EE still remains a construct worthy of further exploration (Macey \& Schneider, 2008; Wollard \& Shuck, 2011). Since its inception in the 1990's (Kahn, 1990), EE has been challenged with issues of concept ambiguity, operationalization and measurement discrepancies (Bakker, Albrecht \& Leiter, 2011; Cole et 
al., 2012; Schaufeli et al., 2002). Despite several studies which have integrated Khan's theory of engagement and have counteracted his work with their own theories (Bakker \& Demerouti, 2007; Maslach et al., 2001; Saks, 2006) to date there is still no one theory of Engagement, which has led researchers to utilize various theories from multiple disciplines, particularly in the field of psychology, sociology and other areas of social science (Saks \& Gruman, 2014). Furthermore, it may be argued that the lack of a specified theory of engagement may have also contributed to the prolonged diffusion between theory and practice, and as such it has been opined that much more is research is needed before the current engagement initiatives can produce the intended results (Wagner, 2015). Nonetheless, employee engagement continues to be a hot topic for organizations, as the outcome as far-reaching impact on positive organizational outcomes, such as increased performance, productivity and business unit outcomes (Bakker \& Bal, 2010; Bakker \& Demerouti, 2007; Harter, Schmidt \& Hayes, 2002; Saks, 2006). Additionally, it has been argued that the previous theories on EE have been limited, and have not examined all the psychological factors involved in engagement (Saks \& Gruman, 2014)

Unfortunately, in spite of the positive effects of EE, the real problem lies in the consequences of disengagement. Disengagement is considered an organization's nightmare, and is defined by Kahn as the decoupling of oneself (Kahn, 1990), and is generally manifested in loss of productivity, absenteeism, turnover, and overall negative organizational outcome (Biro, 2013). These findings have led to major concerns in industry, and present a challenge for $\mathrm{HR}$ managers to develop strategies to mitigate it. Markedly, the understanding of the mechanisms by which specific Human Resource Management Practices (HRMPs) impact on EE, could provide the link in understanding and sustaining EE (Whittington \& Galpin, 2010), possibly because of the organizational benefits researchers have uncovered, noting that organizations with higher employee engagement are more likely to have revenue growth that exceeds their industry average (Markos \& Sridevi, 2010). Owing to the observed potential of employee engagement, past proponents have argued for a continuous research in creating further elucidation of the concept (Wollard \& Shuck, 2011).

Arguably, the common thread in research on HRM and organizational outcome asserts that human resource practices affect organizational performance (Guest, 2011; Lepak, Takeuchi, $\&$ Snell, 2003). However, few of these studies have yet to determine the specifics of why employees perceive the HR practices the way they do, and by what means HRMPs influence their behaviour and engagement (Wright \& Nishii, 2007; Zhang \& Morris, 2014). Most of these studies tend to focus on the type of human resource practices, rather than how these human resource practices are perceived by employees (Khilji \& Wang, 2006; Kooij, Jansen, Dikkers, \& De Lange, 2010). In a study conducted in 2010, a model was developed in which they state that intended HR practices of management are different from the perceived HR practices by employees, and that these perceived HR practices have greater predictive value for organizational outcome than the intended HR practices (Kooij et al., 2010). Consequently, this study aims to provide greater elucidation on the mechanisms responsible for these outcomes, and to add to the further development of what the influencers are of such a dynamic concept such as employee engagement, and the potential influence of a mediating 
relationship of organizational ethical climate (OEC).

\section{Literature Review and Hypothesis Development}

\subsection{Towards a Theory of Understanding Employee Engagement}

In the absence of a specified theory of engagement, scholars have utilized many of the existing theories within the field of psychology to explain the concept of engagement (Saks \& Gruman, 2014). It is widely believed that this has also contributed to the multiple definitions and progressive diffusion regarding the construct. The most widely used theory is Social Exchange Theory (SET), which has been nomologically and empirically used to demonstrate the link between various organizational outcomes and employee behaviours (Bakker et al., 2008; Cropanzo \& Mitchell, 2005; Saks, 2006). SET was first introduced in theory by Blau (1964) on the premise of reciprocity between an employer and an employee. The theory was premised on the actions that are contingent on rewarding reactions from others. These exchanges were implied as two-sided and mutually contingent on reciprocity. The changing workforce brought on by globalization, technological advancement and the changing nature of organization has had far more impact on employees' attitudes and behaviours than we can understand (Pitts-Catsouphes \& Matz-Costa, 2008). Accordingly, employees' needs, desires and what drives their motivation are often misunderstood. Consequently, circumstances of reciprocity are becoming less of a motivation for employees to stay committed in their task or organization (Rich, Lepine, \& Crawford, 2010). Furthermore, according to a recent study, a considerable amount of today's workforce is made up of millennials, and it is said that $38 \%$ are not feeling connected to their organization (Rigoni \& Nelson, 2016). Correspondingly, only $40 \%$ are found to be connected (Mann \& Harter, 2016). In fact, studies have shown that millennials are less concerned about the transactional nature of their jobs, but more about non-financial issues such as the environment and social factors not relating to bottom line (Glavas, 2012; Wrzesniewski, Cameron, Dutton, \& Quinn, 2003).

In light of the foregoing findings, it could be argued that SET may be redundant in the context where rewards are not the main driver of engagement. Furthermore, it begs the question of whether in the absence of an exchange employees would exercise their "discretionary effort" (Wollard \& Shuck, 2011), and rational choice (Hodgson, 2013; Homans, 1958) to determine which decision to make, and decide why and what to engage in. The theory of rational choice (RCT) has its foundations in economics, marketing, sociology and other areas within the social sciences, but in recent times its application have been found useful in the context of human resource management (Hodgson, 2013; Matiaske, 2004). Proponents of the theory have often used it in creating a framework around one's personal decision making, and individualism (Hodgson, 2013). Owing to that, and its multi-discipline application, we may concur that there is a marked correlation between the mechanisms of the theory and that of EE (personal decision and discretionary effort). Even though SET has been repeatedly used, and in many instances applicable in explaining EE, the employee's "self" interest in RCT as a great similarity to that of an employee's "discretionary effort" in employee engagement. Correspondingly, RCT emphasizes how and what determines the choice one makes, while SET depends on a situation of mutual gain and reciprocity to 
influence an employee's behaviour. Furthermore, contrary to the reciprocal rules of SET, EE cannot be demanded, inflated or artificially created (Wollard \& Shuck, 2011) and employees decide whether to exert "discretionary effort" whether there is something to gain or not (Rich et al., 2010). Therefore, it can be argued that a transaction of reciprocity of which forms the basis of the social exchange in SET may not be enough to influence an employee's discretionary effort to become engaged (Rich et al., 2010).

\subsection{Human Resource Management Practices and Employee Engagement}

Research findings and the various gaps in the employee engagement (EE) literature makes it both an enigmatic and interesting concept for further study. Employee Engagement by virtue of its dynamic nature means different things to different interest groups (Simon \& Zhou, 2017). Owing to the positive characteristics of EE such as vigor, dedication and absorption (Schaufeli et al., 2002), EE has been strategized by many business leaders as a business imperative for sustaining competitive advantage (Shuck, Reio \& Rocco, 2011). Consistent with these overt manifestations of EE, organizations have recognized that EE can only come from an employee's discretionary effort (Schaufeli, 2014; Simon \& Zhou, 2017). Therefore, HRM strategies that support HRM practices that are believed to be drivers of EE are implemented to create an environment which will inspire and facilitate the desire for employees to become engaged.

Various research on HRM support the assumption that an employee outcome such as EE is as good as the HRM's ability to implement policies and practices that will engage and satisfy employees as well as impacting competitive advantage (Biro, 2013; Boxall \& Mackey, 2009). Accordingly, HRM practices (HRMP) such as reward and compensation (R\&C), and training and development (T\&D) are considered antecedents to positive organizational outcome such as job satisfaction, increased performance, commitment and turnover intentions (Hong et.al., 2012, Huselid, 1995). Given these positive outcomes, it influences the need to determine how, and by what means HRMPs such as R\&C, and T\&D will impact EE. Previous studies conducted on the relationship between HRMP and EE are few and far between. Similar outcomes such as job satisfaction, commitment, and turnover intentions have been found to be related to EE (Guest, 2011). Additionally, other studies such as HRMP and organization performance (Truss, Alfes, Delbridge, Shantz, \& Soane, 2013), and HRMP and individual outcome (Sparrow, 2014) have also noted the significance among the variables. However, regardless of these ensuing significant relationships supporting the nexus between HRMP and positive organizational outcome such as EE, literature highlights that a gap exists in the understanding of the mechanisms at play in these relationships (Guest, 2011). Furthermore, previous researchers have rarely extended the findings of their empirical studies to accommodate the commercial nature of industry and their need for a practical application of the science.

\subsubsection{Employee Engagement and Reward and Compensation}

In the context of this research, we view rewards and compensation $(\mathrm{R} \& \mathrm{C})$ as one aspect of an organizations compensation scheme. Rewards and compensation is an element of an organization's total reward system which when defined, is considered as a rich mix of 
complimentary initiatives which aim to maximize an employee's chance of finding their work rewarding (Gunnigle, Heraty, \& Morley, 2011; Taylor \& Taylor, 2011), and may contribute to one's engagement (Rowland \& Hall, 2014). We recognize that the holistic approach of looking at $\mathrm{R} \& \mathrm{C}$ may not apply to all employees and does not imply a one-size-fits-all interpretation or solution. In fact, one study has asserted that the uses of multiple reward strategies are often effective in encouraging and re-enforcing positive employee cooperation (De Matteo, Eby, \& Sundstrom, 1998).

Hence, organizations have traditionally used $\mathrm{R} \& \mathrm{C}$ as a means to motivate their employees (Armstrong \& Murlis, 2007), and contribute to EE by delivering on the employers expectation of employees achieving the organizational goals (Hall-Ellis, 2014). Therefore, it may be regarded as an excellent managerial initiative that could influence competitive advantage. Accordingly, Armstrong and Murlis (2007) have opined that R\&C is a type of organizational strategy used to reward and acknowledge employees for their contribution to the organization (Armstrong \& Murlis, 2007). Other researchers have similarly viewed the practice as an attractive organizational practice to assert the organization as an "employer of choice" or a "good place to work" (Mehmood, Qasim, \& Azam, 2013) that is interested in creating an internal environment that is perceived by employees to impact engagement (Gagne \& Deci, 2014; Lawler, 2003; Pfeffer, 1998), and create employee-centred policies and practices to ensure that employees feel valued for their efforts (Armstrong, 2012).

\subsubsection{Employee Engagement and Training and Development}

Studies on Human Resource Management Practices have argued that training and development (T\&D) is among the top influencers of intellectual capacity building and skills competencies within a dynamic workforce (Ijigu, 2015; Nassazi, 2013). Furthermore, it is widely known to have a positive impact on the overall organization (Mone \& London, 2010) as well as create an opportunity where employees' ideas, developments and efforts are invested by the organization (Piening et al., 2014). Among these outcomes are strong correlated antecedents for employee engagement, and as such it is likely that T\&D influence EE.

The causal link between HRMP and EE is questionable, and still unclear, (Arrowsmith \& Parker, 2013) especially based on past research that measured several practices (HRMP bundles) instead of individual practices (Chen, 2017). Hence, the scientific evidence may be misleading to organizations and practitioners causing them to implement and execute HR practices that may or may not give rise to increase levels of EE. Training and Development is a big ticket item for organizations. Studies out of the USA assert that organizations are spending in excess of 70 billion dollars per year in training and development cost (Miller, 2017; Training, 2016). For developing countries like Jamaica, an organization's investment in training may not be up to that level. On the other hand, the war on talent for the best and most highly skilled employees is often the catalyst for organizations to invest in employees training and development initiatives in these competitive labour markets. Furthermore, it has been observed that even though the costs related to training and development, and compensation packages may be considered a costly investment, it has been found to have a 
significant impact when compared to the long-term effect (Thang \& Buyens, 2008). Investing in T\& D is likely to give an organization the competitive edge, and has significant value to both the individual and the organization (Mone \& London, 2010) and lead to employee engagement (Bhattacharya \& Mukerjee, 2009). Furthermore, it has been asserted that employees' attitude and behaviour may be influenced by their perception of HRMP, and the organization's motive for implementing it (Nishii, Lepak, \& Schneider, 2008). In fact, the causal link between HRMP and EE becomes more interesting, as a recent study mediated by EE found that HRMPs (compensation, reward system and training and development were related to how employee felt about their organization (Tangthong, Trimetsoontorn, \& Rojniruntikul, 2014). Additionally, there are still areas that are unclear between the behavioural mechanisms of the two variables, even when a mediator may be involved (Alfes, Shantz, Truss, \& Soane, 2014). Therefore, in this study we first hypothesized (H1) that HRMPs are expected to have a significant impact on EE.

\subsection{Human Resource Management Practices (HRMPs) and Organizational Ethical Climate $(O E C)$}

It is widely known that management plays a significant role on climate perceptions of employees (Dickson, Smith, Grojean, \& Ehrhart, 2001) as they are responsible for the implementation of the human resource management practices in the organization. In light of this, it was hypothesized that HRMPs may have an impact on the ethical climate of the organization. The ethical climate within an organization is deemed to be an encapsulation of the standard of decision-making when faced with issues concerning ethical implications (Cullen, Parboteeah, \& Victor, 2003). Additionally, it is defined as the shared perception of what ethically correct behaviour is and how ethical issues should be handled (Victor \& Cullen, 1987).

However, generally speaking, organizational climate has been described as "the feeling in the air" that one gets from walking around the company (Schneider, Gunnarson, \& Niles-Jolly, 1994). Past proponents have emphasized the importance of a particular kind of climate such as having the "right" type of climate (Argyris, 1958). In fact, human resource management practices were found to be powerful antecedents of different types of organizational climates (Way \& Johnson, 2005). However, the specific mechanism at play in the HRMPs-OEC relationship is still unclear and underexplored (Parboteeah, Chen, \& Lin, 2010; Simha \& Cullen, 2012). Owing to that the theorization of the relationship was inspired by the work of Bowen and Ostroff (2004) wherein they argued that organizational climate may have some connection between HRM practices and various organizational outcomes. They opined that organizational climate is a shared perception of what the organization is in terms of practices, policies, procedures, routines and rewards, and as such it is likely to impact the ethical climate as well as the employee's perception of the climate (Bowen \& Ostroff, 2004). In fact, it has been observed that ethical climate is developed from the repeated perception of the ethical decision-making norms that occur over time within the organization (Jackson, Mun, \& Park, 2013). That notwithstanding, the current gap exists in HRM research which indicates limited empirical findings on the proposed impact of HRM practices on organizational ethics. In fact, only a few have tested the hypothesized impacts empirically, and have done so by 
focusing on the training practices within HRMPs (Sekerka, 2009). Owing to this uncertainty that exist in terms of the specific impact of HRMPs on OEC (Parboteeah et al., 2010) this study investigated and contribute to the lacunae that exist in the HRM-OEC literature. Thus, it was hypothesized (H2) that Human Resource Management Practices will influence organizational ethical climate.

\subsection{Organizational Ethical Climate and Employee Engagement}

Financial Institutions have been looking at employee engagement as a catalyst for positive organizational outcomes in today's competitive environment (Gallup, 2013; Lockwood, 2007). Antecedents of EE are dynamic and vary across various domains, disciplines and culture. In fact, due to the dynamic nature of human behaviour, antecedents of EE are not consistent and may change based on context or situation (Simon \& Zhou, 2017). Consequently, it is the aim of HRM to consistently understand the multi-faceted aspects of organizational variables such as climate, and how it impacts an employee's behaviour. In this study we argue that organizational ethical climate may have an impact on employee engagement. Previous research works have highlighted the potential impact of climate conditions of an organization on employees' behaviour (Cullen et al., 2003; Schwepker 2001). Conditionally, these consequences would have an impact on the organization, and as such the specific mechanisms involved in the relationship are examined based on past findings which have suggested that perceptions of ethical climate are likely to impact an individual's behaviour towards work and organization (Martin \& Cullen, 2006). Furthermore, hypothesized consequences of ethical climate include organizational commitment, psychological well-being and job satisfaction (Martin \& Cullen, 2006; Parboteeah et al., 2010). The likely relationship between OEC and EE are important to examine because a positive relationship would be indicative of the outcomes associated with maintaining a positive ethical climate. Owing to that it may be expected that if the ethical climate is positive it could in fact influence employee engagement. Hence this study hypothesized (H3) that HRMPs will have increase predictor impact on EE when mediated by OEC.

\subsection{Corporate Sustainability and Employee Engagement}

Corporate Sustainability (CS) is often used interchangeably with corporate social responsibility (CSR) which is defined as "context-specific organizational actions and policies that take into account stakeholders' expectations and the triple bottom line of economic, social, and environmental performance" (Aguinis, 2011). In this study corporate sustainability refers to "a company that seeks to create long-term value to stakeholders by embracing the opportunities and managing risks that result from balancing economic, environmental, and social responsibility (Lazlo \& Zhexembayeva, 2011).

Recent studies have asserted that employees are seeking to find meaning and fulfillment at work, and as such employees of organization's that engage in sustainability or corporate social responsibility initiative have shown significance to the behaviour and may contribute to employee engagement (Glavas, 2011; Kao, Ho, Wu, \& Lee, 2009). Even though it has been cited that only a few studies have considered EE as an outcome of CSR (Albdour \& Altarawneh, 2012), others have pointed to the relatedness of the construct on employee 
behaviour and EE (D’Aprile \& Talo, 2015; Rupp, Shao, Thornton, \& Skarlicki, 2013). In fact, most of the previous studies concentrated on the construct as either the predictor or outcome variable, and at the macro level of analysis (Aguinis \& Glavas, 2012; Jones, 2010). This has made way for further enquiry at the micro level of analysis, and from the perspective of the employees. Hence, studies that have investigated the effects of sustainability on employee behaviour have informed of various outcomes such as organizational citizenship behaviour (OCB), job satisfaction and other factors similar to the drivers of EE (Caligiuri et al., 2013; Podsakoff, Whiting, Podsakoff, \& Blume, 2009; Rupp \& Mallory, 2015). Nonetheless, the premise on which these findings have demonstrated the various impact of CS on employees' behaviour, will inform this study of the employees perception of its relatedness to their engagement. In accordance to Aguinis \& Glavas (2012) organizations should consider incorporating sustainability to other aspects of the organization. The study supports this assertion, and proposes that CS be incorporated as a strategic business imperative that will not only impact employee engagement, but also competitive advantage (Garcia-Castro et al., 2010; Podsakoff et al., 2009). It was therefore hypothesized (H4) that mediation effect of OEC will increase the predictor impact of CS on EE.

\subsection{Mediation Analysis}

Past research suggest that HRMPs are believed to have an impact on different types of organizational climate (Parboteeaha, Serikib, \& Hoeglc, 2014; Thite, 2013; Way \& Johnson, 2005). However, little is known of the impact of the overall practices on ethical climates (Parbooteah, 2010; Thite, 2013). According to a study done by Sekerka (2009) training practices were said to impact ethical climates. A cursory view of the climate literature revealed that HRMPs and OEC are distinctly different theoretically, and also how they influence outcomes (Arulrajah, 2015; Mantroop, Singh, \& Ezzedeen, 2014). Much of the relatedness between HRMP and OEC comes from the fact that HRMPs are embedded in ethical considerations (Mantroop et al., 2014; Martin \& Cullen, 2006). In fact, past proponents have opined the significance of HRM in fostering an ethical climate within the organization (Parbooeetha, 2014; Thite, 2013). Furthermore, OEC has been used in previous research as mediator (Ensari \& Karabay, 2016; Mayer, Kuenzi \& Greenbaum, 2010). Implicit of past research it was hypothesized that OEC may mediate the relationship between HRMPS and EE. Additionally, recent studies examining the mediating impact of OEC in the financial sector has shown that OEC may have either indirect or direct on various organizational variables (Elci, Karabay, \& Akyuz,, 2015; Schminke et al., 2005; Shin, 2012). In this study the simple mediation model conceptualized as illustrated in Figure 1, was used.

A study done by Glavas (2016) highlighted that a gap exists in the understanding of how corporate sustainability (CS) impacts employee engagement (EE) (Glavas, 2016). To date other studies have contributed various theoretical and proposed conclusions about the relationship (Glavas \& Piderit, 2009; Kao et al., 2009). In fact, there is a significant dissonance in the understanding of the specific mechanisms in the construct which influences employees' behaviour (Glavas \& Piderit, 2009; Rupp \& Mallory, 2015). Similar studies have found significance between perceived CSR and employee identity (Jones, 2010), job satisfaction (Glavas \& Kelley, 2014), meaningfulness (Rosso, Dekas, \& Wrzesniewski, 2010) 
and organizational citizen behaviour (Lee \& Kim, 2015). Additionally, it has been opined that employees' positive behaviour is increased as a result of their identification of their organization's corporate social responsibility (Farooq, Rupp, \& Farooq, 2017; Shen \& Benson, 2016). Since the dimensions of corporate sustainability are etched in ethical practice and regulatory requirements, it is theorized that the ethical climate within the organization could also be influenced (Rupp, Shao, Thornton, \& Skarlecki, 2013). Furthermore, due to other studies done in the financial sector with OEC as the mediating variable, this study made the assumption that there might be an influence (Elci et al., 2015; Ensari \& Karabay, 2016; Schminke et al., 2005). Therefore, this study's hypothesis was influence by the findings in the literature, and the fact that organizational ethical climate was found to have a mediating impact on various organizational variables (Schminke et al., 2005).
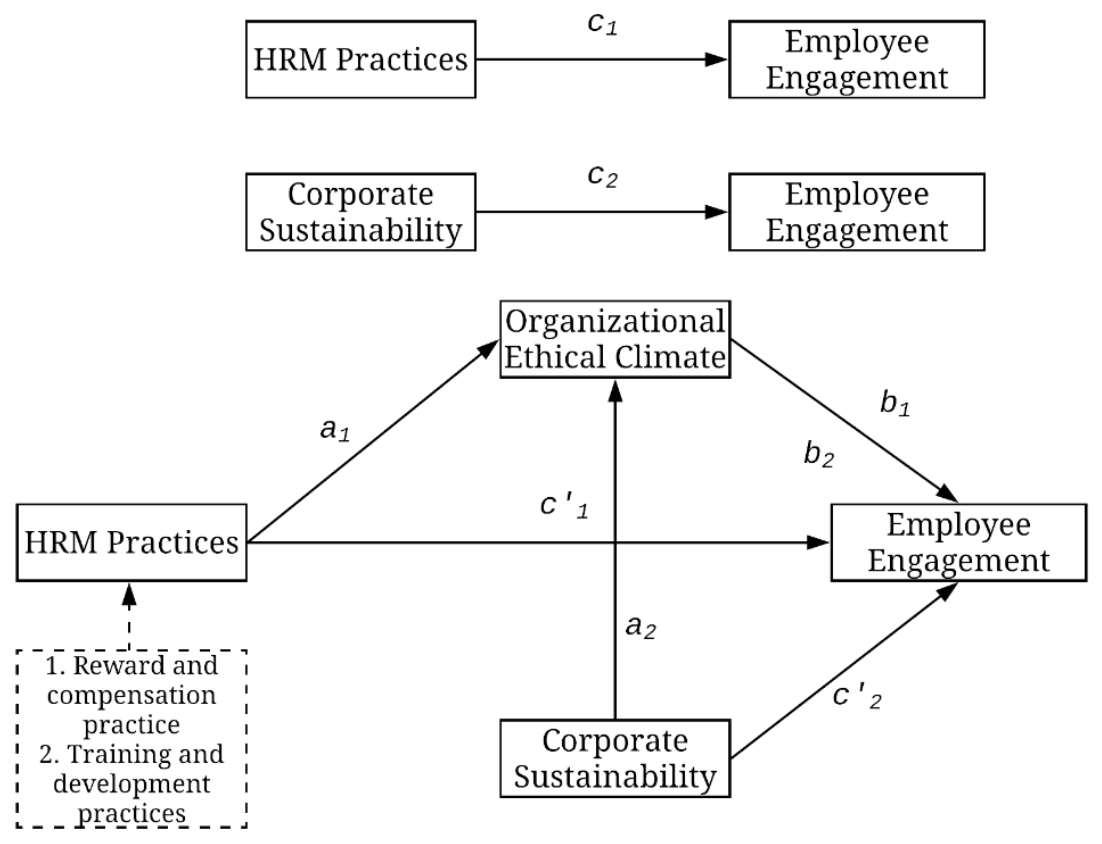

Figure 1. Conceptual model depicting HRM practices, OEC, and EE relationships. $\mathrm{c}_{l}$ and $\mathrm{c}_{2}$ indicates total effect of HRMPs, and CS on EE; $\mathrm{c}_{1}{ }_{1}$ and $\mathrm{c}_{2}{ }_{2}$ are indirect (mediation) effects of OEC on the HRMPs-EE, and CS-EE relationships; $\mathrm{a}_{1}, \mathrm{a}_{2}, \mathrm{~b}_{1}$, and $\mathrm{b}_{1}$ are regression coefficients for their respective relationship between two variables.

\section{Methodology}

\subsection{Participants and Procedure}

I Data was collected from employees of a Commercial Bank in Kingston, Jamaica. The organization is one of great repute and has a long history in the country. It is a publicly traded company and is listed on the Jamaica Stock Exchange. The sample consisted of 130 out of about 275 employees from the Bank's Headquarters, and a convenience sampling approach was utilized. The sampling techniques was most suited for the Head Office staff as that location as they represented a good mix of the overall organization in terms of skills set, experience, and knowledge of the organization plus other demographic factors important to the study. A self-administered questionnaire survey was used to capture employees' responses, 
and accessed online via a Survey Monkey link provided. A sample of the questionnaire is presented in Appendix 1. We investigated the influence of employ demographic and organizational characteristics on employee engagement, respondents' information such as gender, age, level of education, tenure, position and department were captured.

\subsection{Measures}

The questionnaire consisted of 15 validated items which sought to measure respondents' perception on the variables in this study, namely HRMPs (specifically reward and compensation practice, and training and development practices), organizational ethical climate, corporate sustainability, and employee engagement. Each construct or sub-construct had at least three items; and for each item respondents' answers were captured using a 5-point Likert scale $(1=$ Strongly disagree, 2 = Disagree, $3=$ Neutral, $4=$ Agree, and $5=$ Strongly agree). The reliability of the scales for each construct was assessed based on their Cronbach's alpha values, presented in Table 1, and values greater than .7 imply reliability of the scales (Field, 2013).

Six items were adapted from HRMQ 17 item scale by Sanders et al. (2008) to measure employees' perception about the Human Resource Management Practices (HRMPs) in the organization, with three questions each for Reward and Compensation (R\&C), and Training and Development (T\&D). Sample questions included: "the reward management practice in this organization is fair"; "I am satisfied with my overall compensation" and "there are many opportunities to learn and grow both personally and professionally". For a two-factor structure, the reliabilities of R\&C and T\&D were lower: the Cronbach's alpha values for the two constructs were .799 and .754 respectively. However, for a one-factor structure which included all six items of HRMPs, the Cronbach's $\alpha$ value was .830 indicating higher reliability for further analysis.

Table 1. Cronbach's $\alpha$ values for hypothesized variables

\begin{tabular}{lcccc}
\hline & $\begin{array}{c}\text { Valid } \\
\text { Cases }\end{array}$ & $\begin{array}{c}\text { Cronbach's } \\
\alpha\end{array}$ & $\begin{array}{c}\text { Cronbach's } \alpha \\
\text { Based on } \\
\text { Standardized } \\
\text { Items }\end{array}$ & No. of Items \\
\hline HRM Practices & 126 & .830 & .830 & 6 \\
*Reward and compensation practice & 128 & .798 & .799 & 3 \\
*Training and development practice & 128 & .752 & .754 & 3 \\
Organizational ethical climate & 129 & .611 & .612 & 4 \\
Corporate sustainability & 128 & .867 & .867 & 4 \\
Employee engagement & 126 & .807 & .799 & 5 \\
\hline
\end{tabular}

Note: *2-factor structure latent variables for HRM practices

The Gallup Q12 (Harter et al., 2016) was adapted to measure employee engagement: five questions that asked about engagement at work were chosen for the questionnaire. The items included "I know what is expected of me at work", "I have the materials and equipment I 
need to do my work right", and "Considering everything, would you say that you are satisfied in your job and the organization?" The Cronbach's $\alpha$ value was .807 , indicating highly reliability.

For Organizational Ethical Climate 4 items were taken from ECQ (Victor \& Cullen, 2006). Sample questions included, "People are expected to do anything to further the company's interests" and "it is very important to follow strictly the company's rules and procedures here." The internal consistency for OEC was however relatively low, as the Cronbach's $\alpha$ was 0.611 , and no item deletion resulted significant improvement of the reliability of the scales.

Four items for Corporate Sustainability were adapted from PCSR (Glavas, 2012). Sample questions included: "I am aware of a sustainability agenda - in terms of management attention and investment in your company?" and "Your organization's sustainability agenda influence you to exert extra effort and engage in behaviours that contribute to your organization's success?" The Cronbach's a values were .867, implying high internal consistency of the scales.

\subsection{Data Analysis}

Data analysis was done by employing statistical tools such as ANOVA and T-test to assess whether or not the demographic and organizational characteristics of employees affected their employee engagement. Mediation analyses were conducted using version 2.16.3 of SPSS PROCESS macro (Hayes, 2013) to explore the mechanisms by which the predictors (HRMPs and CS) transmitted their effects onto EE. Model 4 was selected for simple mediation analysis, with 2000 bootstrap sampling at $95 \%$ confidence interval (CI). The bias-corrected bootstrap CI method was used, as it is widely recommended over percentile bootstrap CI or Monte Carlo CI method (Hayes, 2013). The results for total, direct, and indirect effects were analyzed. The significance level of the indirect effect which indicate mediation or otherwise was tested using the Sobel test (or Normal theory test), but this was cross-checked with the bootstrapping method.

\section{Results}

\subsection{Descriptive Statistics}

The study involved 130 respondents, consisting of $23.1 \%$ males and $76.9 \%$ females. About a quarter $(25.2 \%)$ of the respondents were in their forties, while $11.0 \%$ were 50 years old or older. The average age of respondents was about 30 years $(29.59$ years, $S D=2.98)$ if the pension age is set at 65 years, with about half (48.8\%) being from $20-35$ years. Majority $(87.7 \%)$ occupied a non-managerial position, while the remaining were managers. Also, most $(40.6 \%)$ of the respondents were from the retail/sales department, with $21.9 \%, 17.2 \%, 11.7 \%$, and $8.6 \%$ from the Customer Service unit, Head office, Operations, and the Administration departments respectively. Almost half (47.6\%) of respondents have worked with the organization for over ten years, $19.8 \%$ for $6-10$ years, $25.4 \%$ for $1-5$ years, and $7.1 \%$ for less than a year. The scores of respondents and distribution in relation to HRMPs (R\&C and EE), OEC, CS and EE are shown in appendix 2. 
On the issue of reward and compensation $(\mathrm{R} \& \mathrm{C})$ practice, majority of respondents $(56.2 \%)$ agreed or strongly agreed that "the reward management practice in this organization is fair" (Q1), about a quarter of them (25.4\%) were of 'neutral' opinion, and $18.4 \%$ disagreed or strongly disagreed. Similarly, majority $(60.0 \%)$ agreed or strongly agreed that employees were rewarded equitably based on performance (Q2), whilst $19.2 \%$ disagreed or strongly disagreed; the rest were neutral. On the item I am satisfied with my overall compensation (Q3), however, over a quarter of respondents (27.3\%) had a neutral opinion, $42.2 \%$ agreed or strongly agreed, and 30.5\% disagreed or strongly disagreed. The mean $(\bar{x})$ and standard deviations $(S)$ of the scores of Q1 to Q3 were: Q1 $\left(\bar{x}=3.36, S D_{N=130}=.92\right), \mathrm{Q} 2(\bar{x}=3.43$, $\left.S D_{N=130}=.96\right)$, and Q3 $\left(\bar{x}=3.12, S D_{N=128}=.98\right)$.

The results on the training and development (T\&D) practices in the organization also revealed that over $80 \%$ agreed or strongly agreed that "there is a commitment to on-going training and development of employees" (Q4), and almost $30 \%$ in this category strongly agreed. Less than $10 \%$ disagreed or strongly disagreed to this whilst $11.5 \%$ shared a neutral opinion. Moreover, half of respondents $(50.0 \%)$ agreed that there are many opportunities to learn and grow both personally and professionally (Q5); $23.4 \%$ strongly agreed, $16.4 \%$ were neutral, and $10.2 \%$ disagreed or strongly disagreed. Majority (65.4\%) also agreed or strongly agreed to I am satisfied that I have the ability to utilize my talents and expertise on the job (Q6), while $16.2 \%$ were of the contrary opinion, and the rest neutral. The mean scores and standard deviations for Q4, Q5, and Q6 were Q4 $\left(\bar{x}=3.95, S D_{N=130}=.88\right)$, Q5 ( $\bar{x}=3.83$, $\left.S D_{N=128}=.99\right)$, and Q6 $\left(\bar{x}=3.61, S D_{N=130}=.99\right)$.

For the items that captured employees' perception on organizational ethical climate, about $43.1 \%$ agreed or strongly agreed that employees are expected to do anything to further the company's interests (Q7), 29.3\% disagreed or strongly disagreed, with the remainder giving a neutral response. Majority $(86.1 \%)$ accepted that it was very important to follow strictly the company's rules and procedure (Q9); and 40\% in this category strongly agreed. Less than $10 \%(8.4 \%)$ of the total respondents disagreed while $5.4 \%$ were neutral on the issue. Quite strikingly, it was observed that most respondents were neutral on "People are concerned with the company's interests - to the exclusion of all else" $(\mathrm{Q} 8)$ and "Successful people in this company strictly obey company policies" (Q10). 40.3\% of respondents were neutral, 26.4\% agreed or strongly agreed, and $33.3 \%$ disagreed or strongly disagreed to Q8. Also, as to whether successful people in the company strictly obey the company's policies (Q10), 38.5\% were neutral, as against $36.1 \%$ who agreed or strongly agreed and $25.4 \%$ who disagreed or strongly disagreed. The mean scores and standard deviations for Q7, Q8, Q9 and Q10 were Q7 $\left(\bar{x}=3.61, S D_{N=130}=.99\right), \mathrm{Q} 8\left(\bar{x}=3.18, S D_{N=129}=1.16\right), \mathrm{Q} 9\left(\bar{x}=2.93, S D_{N=130}=.99\right)$, and $\mathrm{Q} 10\left(\bar{x}=4.08, S D_{N=130}=.99\right)$.

On corporate sustainability, though majority $(60.8 \%)$ of the respondents agreed or strongly agreed, and $7.5 \%$ disagreed or strongly disagreed that they were aware of a sustainability agenda of the organization (Q11), quite a substantial portion $(31.5 \%)$ were neutral. Similarly, most (61.3\%) admitted that the company's sustainability agenda influences them to contribute better to the organization (Q12), while $11.7 \%$ were of the contrary opinion, and $27.1 \%$ were neutral. Majority $(72.1 \%)$ of the respondents also admitted that the organization's practices 
and policies are influenced by sustainability (Q13), but $18.6 \%$ were neutral while $9.4 \%$ disagreed or strongly disagreed. Also, $71.9 \%$ believed that sustainability has an influence on the ethical climate of the company (Q14), and a quarter of respondents in this category strongly agreed. Meanwhile, $22.7 \%$ expressed a neutral opinion and 5.5\% disagreed. The mean scores and standard deviations for Q11, Q12, Q13 and Q14 were Q11 $(\bar{x}=3.66$, $\left.S D_{N=130}=.86\right), \mathrm{Q} 12\left(\bar{x}=3.61, S D_{N=129}=.90\right), \mathrm{Q} 13\left(\bar{x}=3.83, S D_{N=129}=.91\right)$, and Q14 $(\bar{x}=$ 3.83, $\left.S D_{N=128}=.82\right)$.

\subsection{Influence of Employee Demographic and Organizational Characteristics on Engagement}

Both $T$-test and analysis of variance (ANOVA) were conducted to examine the relationship between the control variables (employees' demographic and organizational characteristics) and their job engagement, and the results are presented in Appendix 3. T-test was applied to dichotomous variables like gender and employee position (whether manager or non-manager), whilst ANOVA was used for variables with more than one categories. No significant difference in employee engagement levels was observed with respect to the gender of employees $(t=-1.547, p>.05)$. Similarly, the difference observed among different age groups $(F=1.464, p>.05)$, and employees' level of education $(F=.324, p>.05)$ were not significant. Hence, employees' demography indicated no difference regarding their levels of engagement.

In the case of organizational attributes, employee engagement was not affected by whether employees were managers or non-managers $(t=-.653, p>.05)$, or the unit/department in which they worked $(F=.324, p>.05)$. However, how long employees have served the company had significant relationship with their level of engagement $(F=2.833, p<.05)$. Employees who had been with the company for less than a year had high scores for employee engagement $(\bar{x}=4.11, S D=.40)$, followed by those with over 10 years of service $(\bar{x}=3.60$, $S D=.81)$, those who have served from 1 to 5 years $(\bar{x}=3.50, S D=1.01)$, and those with 6 to 10 years of service $(\bar{x}=3.19, S D=.81)$.

\subsection{Predictor Mechanism of Human Resource Management Practices (HRMPs), and Corporate Sustainability (CS) on Employee Engagement (EE)}

\subsubsection{Mediator Effect of OEC on the HRMPs-EE Relationship}

In the model where the mediator (OEC) was absent (Fig. 2a), HRM practices significantly predicted employee engagement $\left(c_{1}=.032, t=7.78\right.$, CI [.024, .040], $\left.p<0.001\right)$, indicating a positive relationship; and this model explained $33.5 \%$ of the variance in employee engagement $(F(1,120)=60.56, p<.001)$. When OEC was included (Fig. 2b), HRM practices still showed significant prediction of employee engagement $\left(R^{2}=.389, c^{\prime}{ }_{1}=.030, t\right.$ $=7.38$, CI $[.022, .038], p<0.001)$. The Sobel test showed a non-significant indirect effect of OEC on the HRMPs-employee engagement relationship $(b=.002, z=1.63, p>0.05)$, indicating no mediation. But inferences of the bootstrap confidence intervals $(\mathrm{BaCI})$ are considered more likely to be accurate compared to the Sobel test since the confidence intervals better respect the irregularity of the sampling distribution (Field, 2013; Hayes, 2013). The bootstrapping method indicated significant indirect effect HRM practices on employee 


\section{Macrothink}

International Journal of Human Resource Studies

ISSN 2162-3058 2018, Vol. 8, No. 2

engagement through OEC: the completely standardized indirect effect was $b=.042,95 \%$ BCa CI $[.003, .121]$. Since the bootstrap confidence intervals contained no zero, a genuine mediation could be said to exist.

\subsubsection{Mediator Effect of OEC on the CS-EE Relationship}

We also investigated the hypothesis that OEC mediates the relationship between an organization's corporate sustainability and employee engagement, and the results are presented in Figure 3. If the impact of OEC is ignored (Fig. 3a), corporate sustainability has significant positive effect on employee engagement $\left(R^{2}=.177, b=.399, t(124)=5.13\right.$, CI $[.24, .55], p<0.001)$. A consideration of the impact of OEC however shows that the direct effect of CS on EE is $b=.348, t(124)=4.69$, CI $[.20, .49]$; OEC also showed relatively stronger, and significant positive effect on $\mathrm{EE}\left(R^{2}=.177, b=2.007, t(124)=4.91\right.$, CI [1.03, 2.98], $p<0.001)$. According to the Sobel test, the indirect effect is not significant $(b=.050, z$ $=1.65, p>0.05)$. Conversely, the bootstrapping method shows a significant indirect effect, hence indicating that there is mediation of CS and EE by OEC. The regression for the completely standardized indirect effect was $b=.053, S E=.033$, Ba CI $[.002, .136]$.

a.

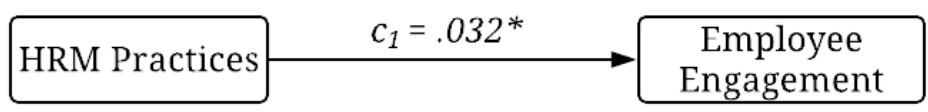

b.

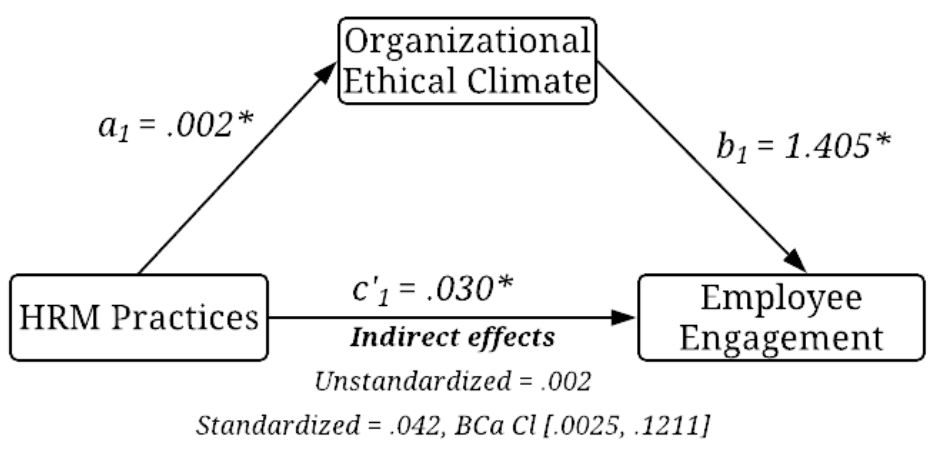

Figure 2. Standardized regression coefficients for the relationship between HRM practices and employee engagement: $a$. with no mediation, and $b$. as mediated by organizational ethical climate. $* p<.05$ 
a.

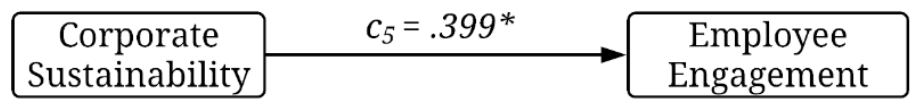

b.

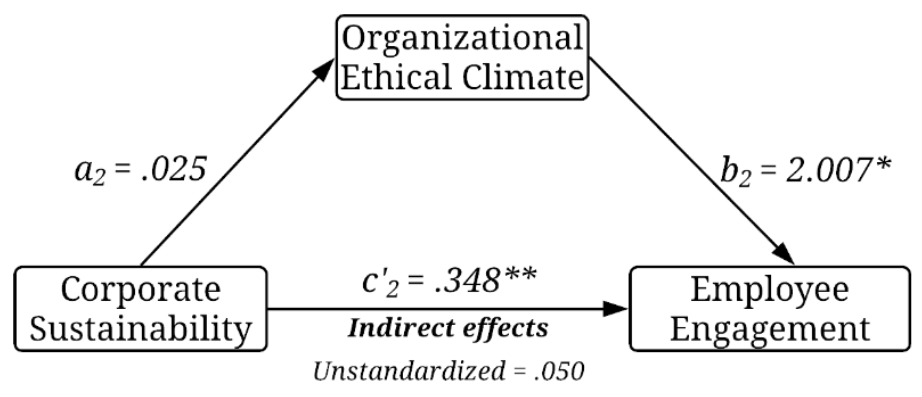

Standardized $=.053, \mathrm{BCa} C l[.002, .136]$

Figure 3. Standardized regression coefficients for the relationship between corporate sustainability and employee engagement: a. with no mediation, and b. as mediated by organizational ethical climate. $* p<.05, * * p<.01$.

\section{Discussion}

The present study was designed to determine the effects of human resource management practices (HRMPs) on employee engagement (EE). Previous studies evaluating the same relationship have observed inconsistencies in the results on the specific mechanisms at play in this relationship (Guest, 2011; Wright \& Nishii, 2007). Accordingly, the present inconsistencies have presented a gap which this study have sought to elucidate by introducing a mediator variable to offer additional insights into how these conceptualized relationships will unfold.

\subsection{Influence of Employee Demography and Organizational Profile on Employee Engagement}

The study revealed that among the six employee profile variables considered in this study (i.e. gender, age, level of education, position, department, and tenure), only the tenure of employees was a determinant of EE. A similar study by Rigg (2012) however showed that among the variables, only age and department of work had significant relationship with EE. Those who just joined the organization and those who had been working there for over 10 years. Quite interestingly, apart from employees with age above 50 years, the millennials (20-29 years) had higher scores on engagement $(\bar{x}=3.7, \mathrm{SD}=.99)$ as shown in appendix 3 ; and this is contrary to findings of previous studies that they are the most difficult and least engaged (Rigoni \& Nelson, 2016). In addition, those in managerial position and have tenured could show engagement due to their level of maturity, commitment and other positive job attributes perceived by them( Simpson, 2009). This assumption has also been echoed in other studies that found that new recruits (under 1 year) and the tenured employees (over 11 years) (Pitt-Catsouphes \& Matz-Costa, 2008; Simpson, 2009) were more engaged than those in the middle. A seemingly appropriate assumption is that millennials and those just entering the organization are enthusiastic about the future and the jobs, than those who are in the middle 
(5 to 10 years) that this study revealed were neutral. Unfortunately, the group whose tenure ran from 5 to 10 years consisted of the majority of the sample's workforce and could be indicative of their feeling of psychological contract breach or experiencing burn- out (Truss, et al., 2006). Similarly, Brim (2002) opines that employees' engagement levels tend to decline the longer they stay in the organization. However, the findings in this study had the reverse outcome of Brim (2002) and Buchingham (2001) study, as the tenured employees were shown to be engage.

\subsection{Influence of HRM Practices on Employee Engagement}

The first objective of this study was to determine by what means HRMPs influence EE. It was found that both factors of the construct (1) reward and compensation (R\&C) and (2) training and development (T\&D) had an impact on employee engagement. However, training and development (T\&D) showed a stronger impact on EE. Also, though a fair majority (55\%) of the respondents believed the reward and compensation practices in the organization is fair, less than half were satisfied with the overall compensation received from the company. This outcome could be indicative of a cohesive mindset among employees that their reward and compensation may not match their efforts on the job. This is congruent with other studies where employees had different perceptions about rewards, and where their pay satisfaction was perceived by what they believe their efforts were worth (Bozeman \& Gaughan, 2011; Kominis \& Emmanuel, 2005). Therefore, this might explain why the employees in the bank appeared to be neutral towards the overall compensation. Furthermore, other studies have cited employees' indifference to $\mathrm{R} \& \mathrm{C}$ as a perception of inequity of the compensation system within their organization (Forest \& Gagne, 2011; Kuvaas, 2006). Interestingly, even though other studies have shown the positive impact of $\mathrm{R} \& \mathrm{C}$ in various organizational settings, most of those studies were conducted outside of the Caribbean cultural and organizational setting. In fact, this conception is consistent with the outcome of a survey that was done in China, Japan, Germany and the USA, which revealed that employees in different countries had different perception and preference to their organization's reward system (Gunkel, Lusk, \& Wolff, 2009).

Globally there is a war on talent, and organizations recognize that training is an avenue for competitive advantage. The findings in this study showed that the bank's employees were more engaged by the training and development practices. Similar, outcomes have been cited on HRMPs and EE (Qureshi, Warmat \& Ramay, 2007; Singh, 2004) both studies investigated bank employees and observed that training and compensation had a significant impact on employee's behaviour. A possible explanation to this observation could be that the organization places significance on training and it may be linked to promotion and other intangible rewards linked to an employee's opportunity for development. In fact, this assumption is evidenced by the responses to the question as a greater portion of the employees (80\%) agreed that there is "ongoing training and development of employees in the organization". The findings broadly support the findings of other similar research (Hatcher, 2002). Markedly, more than $70 \%$ agreed on the organizations commitment to training and personal and professional capacity building. This could be that within the organization's training and development could be tied to promotion and other intangible benefits which may 
influence their perception of the workplace policy (Holbeche \& Springett, 2003). Furthermore, strong positive correlation was observed between provision of opportunities and the company's commitment to employee's capacity building. The company's commitment to training and development programmes for employee also showed a moderate positive correlation with employees' satisfaction with their ability to utilize their talents and expertise on the job. Additionally, employees tend to engage when they perceive that the organization is investing in their personal development (Crawford, Rich, Buckman, \& Bergeron, 2014). These therefore suggest that the training and development practices in the company are generally very satisfactory. Even though the findings have revealed this significance, due to the changing nature of an employees' engagement level, it is suggested that the organization embark on consistent and innovative training and development programmes that have the ability to enhance employee engagement. Due to the fierce competition in the sector, changes in technology, the regulatory environment along with the war for talent aligned with these conditions, the HRM should necessitate training initiatives as a part of the EE strategy to mitigate threats and enhance a highly skilled workforce. Contrary to what was expected, the findings on $\mathrm{T} \& \mathrm{D}$ had a stronger impact on banking employees than R\&C. However, because perception and behaviour varies, the expected outcome that both factors would be perceived highly by employees, confirms the arguments of Nishii et al. (2008). This study has produced results that showed a high level of significance, and as such failed to reject Hypothesis one (H1). Hence, HRMPs do have a significant impact on EE

\subsection{Influence of HRM Practices on Organizational Ethical Climate}

Previous studies have suggested that by the virtue of HRM there should be a positive relationship between HRMPs and organizational ethical climate (OEC) However, the extent to the relationship is limiting (Thite, 2013). In this study, T\&D was found to have high correlation to OEC which corroborate previous findings (Brown, 1995; Hatcher, 2002; Vuuren \& Eiselen, 2006) that training has a significant impact on the ethical climate in an organization. Surprisingly, in this study R\&C showed no impact on OEC. In fact, employees were moderately influenced and felt that the overall $\mathrm{R} \& \mathrm{C}$ in the organization was fair, even though only $40 \%$ was satisfied with it. This could also be indicative of our previous findings on the relationship between $\mathrm{R} \& \mathrm{C}$ and EE. It could be that employees within this bank are really not strongly influenced by the reward and compensation structure as discussed previously. Significantly, our finding contradicts previous studies that have suggested that organizational climate can be influenced by a reward system (Jansen \& Von Glinow, 1985). As we have seen in the previous results it appears that employees within this bank are more influenced and engaged by training and development opportunities. However, overall the study showed that HRMP does impact OEC. Hence, these results provide further support for the hypothesis two (H2) HRMPs will influence OEC.

\subsection{Effect of Organizational Ethical Climate and Employee Engagement}

The mediation effect OEC on increasing the influence of HRMPs, and CS has been shown in this study (see section 4.3), thus supporting hypotheses 3 and 4 (H3 and H4). Though the results in Figure 2 and 3 show that OEC significantly influences EE, the findings proved 
inconclusive as establishing a general observation for respondents' views on the organization's ethical climate was quite complicated. First, a striking portion $(30-40 \%)$ of respondents had a neutral opinion on employees' willingness to further the company's interest to the exclusion of all, and as to whether successful people in the organization strictly obey company policies. Moreover, despite majority (over 85\%) admitting that strictly following the organizations laid down rules and procedures is of great importance, the responses also suggested that successful people in the company do not necessarily obey the company's policies as only $36 \%$ agreed. One explanation for this outcome could be influenced by the organizational context. Most employees know that the bank is a principled and highly regulated environment which has sanctions for undesirable conduct. However, the latter 36\% that think that successful people in the organization do not necessarily follow rules is quite unexpected. Similarly, majority $(\sim 40 \%)$ were undecided on the issue of employees prioritizing the organization's interest over others. This may indicate that the engagement within this organization may not be very high. While this is purely speculative, the observation of the previous outcomes have revealed that employees who have done over 5 years in this organization either appear cynical or indifferent, these can be argued as tell-tale signs of disengagement (Buchingham, 2001; Maslach \& Leiter, 2001; Rupp et al., 2010). The issue of ethics has serious implications for all stakeholders within the banking sector; hence the response from the majority agreeing with following company's rules is not surprising. This view is supported by others wherein the outcome of the organization is congruence with the employee's attitude and behaviour and their perception of equity (Flint, Flint, \& Lynn, 2013; Jaramillo, Mulki, \& Boles, 2013; Jaramillo, Mulki, \& Solomon, 2006). However, the critical nature of the organization requires a team that will have a greater perception of the OEC, which based on the responses, appears not to be a major factor in their engagement. This outcome supports the view of Simon and Zhou (2017), in that due to the dynamic nature of EE the drivers of the construct are inconsistent and always changing. Surprisingly, the difference in the findings oppose previous studies that indicated that OEC will likely have an impact on EE (Martin \& Cullen, 2006), and that organizational climate has the ability to influence employee behaviour (Cullen et al., 2003; Schwepker, 2001).

\subsection{Effect of Corporate Sustainability on Employee Engagement}

Sustainability is big business all over the world (Mohrman \& Shani, 2011). However, much of the research on corporate sustainability has been centered on the organization and the macro issues within the firm (Glavas, 2011). This observation has presented a gap in the understanding of the concept from a micro level perspective, and has contributed to the multiple meanings, applications and analysis (Glavas \& Godwin, 2010; Mohrman \& Shani, 2011). The findings in this study present a unique opportunity for practice and the further development of the literature as it relates to human resource studies. Previous studies have questioned the various levels of analysis, and have asserted that the concept may be elusive (Burritt \& Schaltegger, 2010). In fact this study's findings disagree with Burrett and Schellegger's claims, and have conversely revealed a rather significant and unique relationship on employee engagement (EE). These findings may be explained by the mediating effect of OEC on the relationships, which has similar outcome to that of another 
study (Guerci, Radaelli, Siletti, Cirella, \& Rami Shani, 2015). Furthermore, the nomologicaly similarities between HRMP, OEC, and CS grounded in ethics could also influence the relationship and the perceptions of employees (Cullen et al., 2003). In fact, previous studies have supported this view that employees' behaviour toward sustainability and ethical climate is normally influenced by their decision-making and related behaviours. Most other studies would also confer the likelihood of employee engagement seeing that ethical climate was shown to impact job satisfaction (Shin, 2012; Stewart, Volpone, Avery, \& Mckay, 2011), and employee commitment (Schwepker, 2001; Cullen et al., 2003). Another noteworthy factor could be explained by the fact that according to studies, millennials are less interested in the transactional aspects of their jobs, and are more interested and influenced by issues related to the society and the environment (Glavas, 2012; Wrzesniewski et al., 2003). Similarly, these findings are congruent with other studies that argue that an employee's perception of sustainability may influence their engagement (Glavas, 2012; Mohrman \& Shani, 2011; Wrzesniewski et al., 2003).

\subsection{Implications}

To the best of our knowledge, this study is (among) the first to address the specific relationship between perceived HRMPs and EE, and the mediating role of organizational ethical climate in the Jamaican context. Significantly, the research has also uncovered the influence that age and tenure has on the employees' engagement. Specifically age, as there are still limited studies on the specific impact of age (Kooij et al., 2010). Additionally, this study shows that a one size fits all HRMPs will not necessarily be accepted by all in the organization. Of the two practices examined in the study, we found that training and development was what had the greatest impact on employees' engagement. This has significance to practice as HR Leaders and scholars of the discipline may find relevance in widening the scope of the field by developing new or reassessing the HRMP's.

Moreover, as we have stated that the drivers of engagement are not constant (Simon \& Zhou, 2017). We expect to see future studies investigating other organizational factor that could be affecting engagement. Importantly, this empirical study will contribute greatly to the discourse on engagement from a Caribbean perspective, and provide a foundation on which other studies can be built on.

\section{Conclusion}

There is no doubt that the findings in this study will contribute to the elucidation of employee engagement in the Jamaican context. In fact, the outcomes have been shown to have relevance for practice and the findings can be used within the banking sector and establish further relevance in other industries within the country. More importantly, the findings revealed that there is further work to be done in understanding the various factors that drive engagement. The unexpected outcome of employees being more engaged by training and development opportunities, than reward and compensation will indicate to management that money is not necessarily influencing their employees to give more of their discretionary effort. Additionally, it also presents an opportunity to identify the current drivers in order to improve them for sustained engagement. Notwithstanding the changing nature of engagement 
driver (Simon \& Zhou, 2017) organizations can use these findings as a spring board to implementing strategies to enhance employee engagement.

Furthermore, this study indicated that initiatives and strategies on corporate sustainability have an impact of employees' behaviour and subsequently their engagement. The study also showed that there needs to be greater employee education and involvement in issues and strategies relating to the organization's corporate sustainability.

Additionally, our findings indicate that there is power in the perception of employees, and the sooner that organizations begin to involve more of these perceptions into practice and policies the more effective the strategies for employee engagement and other organizational outcome which may translate into positive organizational outcomes. Overall, our results showed that HRMP's related to training and development had far greater impact on employees engagement. Additionally, the findings also indicated that age and tenure also had an impact on employees' engagement. These findings are significant keys to developing strategies and give a narrative of the potential opportunities that exist within the organization that can be used as competitive advantage if harnessed carefully by the HRM.

\section{References}

Aguinis, H., \& Glavas, A. (2012). What we know and what we dont know about corporate social responsibility: A review of research agenda. Journal of Management, 38(4), 932-968. https://doi.org/10.1177/0149206311436079

Albdour, A. A., \& Altarawneh, I. I. (2012). Corporate Social Responsibility and Employee Enagement in Jordan. International Journal of Business and Management, 7, 89-105. https://doi.org/10.5539/ijbm.v7n16p89

Alfes, K., Shantz, A. D., Truss, C., \& Soane, E. (2013). The link between perceived human resource management practices, engagement and employee behaviour: A moderated mediation model. International Journal of Human Resource Management, 24(2), 330-351. https://doi.org/10.1080/09585192.2012.679950

Argyris, C. (1957). Personality and Organization. New York: Harper and Row.

Armstrong, M. (2012). Armstrong's Handbook of Human Resource Management. Kogan

Armstrong, M., \& Murlis, H. (2007). A Handbook of Remuneration Strategy and Practice. Haygroup Ltd.

Arrowsmith, J., \& Parker, J. (2013). The meaning of 'employee engagement'for the values and roles of the HRM function. The International Journal of Human Resource Management, 24(14), 2692-2712. https://doi.org/10.1080/09585192.2013.763842

Arulrajah, A. A. (2015). Contribution of Human Resource Management in Creating and Sustaining Ethical Climate in the Organisations. Sri Lankan Journal of Human Resource Management, 5(1), 7-9.

Bakker, A. B., \& Bal, P. M. (2010). Weekly work engagement and performance: A study among starting teachers. Journal of Occupational and Organizational Psychology, 83, 189-206. https://doi.org/10.1348/096317909X402596

Bakker, A. B., \& Demerouti, E. (2007). The Job Demands- Resources model: State of the art. 
Psychology,

22 ,

309-328.

https://doi.org/10.1108/02683940710733115

Bakker, A. B., Albrecht, S. L., \& Leiter, M. P. (2011). Key questions regarding work engagement. European Journal of Work and Organizational Psychology, 20, 4-28. https://doi.org/10.1080/1359432X.2010.485352

Bakker, A. B., Schaufeli, W. B., Leiter, M. P., \& Taris, T. W. (2008). Work engagement: An emerging concept in occupational health psychology. Work \& Stress, 22, 187-200. https://doi.org/10.1080/02678370802393649

Bhattacharya, S., \& Muckherjee, P. (2009). Rewards as a key to employee engagement: A comparative study on I.T. professionals. ASBM Journal of Management, 2(1) 160-175.

Biro, M. M. (2013). Employee Engagement: Every leader's imperative. Retrieved January 29, 2018 , from https://www.forbes.com/sites/meghanbiro/2013/05/19/employee-engagement-every-leaders-i mperative/

Blau, P. M. (1964). Exchange and power in social life. Transaction Publishers.

Bowen, D., \& Ostroff, C. (2004). Understanding HRM-Firm performance linkages: The role the "strength" of the HRM system. Academy of Management Review, 29(2), 203-221.

Boxall, P., \& Macky, K. (2009). Research and theory on high-performance work systems: Progressing the high involvement stream. Human Resource Management Journal, 19, 3-23. https://doi.org/10.1111/j.1748-8583.2008.00082.x

Brim, B. (2002). The Longer workers stay in their jobs the more disheartened they become. Gallup Management Journal, (March). Retrieved from http://www.gallupjournal.com/GM/Jarchive/issue5/2002315c.asp

Brown, S. P., \& Leigh, T. W. (1996). A new look at psychological climate and its relationship to job involvement, effort and performance. Journal of Applied Psychology, 81(4), 358-368. https://doi.org/10.1037/0021-9010.81.4.358

Buckingham, M. (2011). What a waste. People Management, October, 36-39.

Burritt, R. L., \& Schaltegger, S. (2010). Sustainability accounting and reporting: Fad or trend? Accounting, Audit \& Accountability Journal, 23(7), 829-846. https://doi.org/10.1108/09513571011080144

Caligiuri, P., Mencin, A., \& Jiang, K. (2013). Win-win-win: the influence of company-sponsored volunteerism programs on employees, NGOs, and business units. Personnel Psychology, 66, 825-860. https://doi.org/10.1111/peps.12019

Chen, S. L. (2017). Cross-level effects of high-commitment work systems on work engagement: the mediating role of psychological capital. Asia Pacific Journal of Human Resources. https://doi.org/10.1111/1744-7941.12144

Cole, S., Walter, F., Bedeian, A. G., \& O'Boyle, E. H. (2012). Job burn-out and employee engagement: A meta-analytic examination of construct proliferation. Journal of Management, 38, 1550-1581. https://doi.org/10.1177/0149206311415252

Crawford, E. R., Rich, B. L., Buckman, B., \& Bergeron, J. (2014). The antecedent and drivers of employee engagement. In C. Truss, K. Alfes, \& R. Delbridge (Eds.), Employee Engagement 
in Theory and Practice (pp. 57-81). London: Rouledge.

Cropanzano, R., \& Mitchell, M. S. (2005). Social exchange theory: An interdisciplinary review. Journal of Management, 31(6), 874-900. https://doi.org/10.1177/0149206305279602

Cullen, J. B., Parboteeah, K. P., \& Victor, B. (2003). The effect of ethical climates on organizational commitment: A two-analysis. Journal of Business Ethics, 46(2), 127-141. https://doi.org/10.1023/A:1025089819456

D'Aprile, G., \& Talo, C. (2015). Analysis of Community Empowerment on Projects Sustainability: Moderating Role of Sense of Community. Journal of Science Education \& Technology, 24(5), 671-683.

DeMatteo, J. S., Eby, L. T., \& Sundstrom, E. (1998). Team-based rewards: current empirical evidence and directions for future research. Research in Organizational Behaviour, 20, $141-183$.

Dickson, M., Smith, M. W., Grojean, M. C., \& Ehrhart, M. W. (2001). An organizational climate regarding ethics: The outcome of leader values and the practices that reflect them. Leadership Quarterly, 12, 197-214. https://doi.org/10.1016/S1048-9843(01)00069-8

Elci, M., Karabay, E. M., \& Akyuz, B. (2015). Investigating the mediating effect of ethical climate on organizational justice and burnout: A study on financial sector. Procedia - Social And Behavioral Sciences, 207, 587-597. https://doi.org/10.1016/j.sbspro.2015.10.130

Ensari, M. S., \& Karabay, M. (2016). The mediating effect of perceived ethical climate on organizational commitment, trust and turnover intention interactions: A research on Insurance Sector. European Journal of Business and Social Sciences, 5, 47-63.

Farooq, O., Rupp, D., \& Farooq, M. (2017). The multiple pathways which internal and external corporate social responsibility influence organizational identification and multifoci outcomes: The moderating role of cultural and social outcomes. Academy of Management, 60 (3), 954-985. https://doi.org/10.5465/amj.2014.0849

Field, A. (2013). Discovering Statistics using IBM SPSS Statistics. (4th ed.). Sage Publishers.

Flint, H. D., Flint, H., \& Lynn, M. (2013). Distributive justice in human resources management: A multisystem approach. The Journal of American Business Review, 2(1), $50-57$.

Forest, J., \& Gagne, M. (2011). The study of compensation systems through the lens of self determination theory: Reconciling 35 years of debate. CIRANO Working Papers 2011s-54, CIRANO. https://doi.org/10.2139/ssrn.1923827

Gagne, M., \& Deci, E. L. (2014). The History of Self-Determination Theory in Psychology and Management. In M. Gagne (Ed.), The Oxford Handbook of Work Engagement, Motivation, and Self-Determination Theory. (pp. 1-9). Oxford Library of Psychology, Oxford University Press:UK. https://doi.org/10.1093/oxfordhb/9780199794911.013.006

Gallup Inc. (2013). Engaged Employees Inspire Company Innovation. Retrieved from https://businessjournal.gallup.com/content/24880/gallup-study-engaged-employees-inspire-co mpany.aspx. 
Garcia, C. R., Arino, M. A., \& Canela, M. A. (2010). Does social performance really lead to financial performance? Accounting for endogeneity. Journal of Business Ethics, 92(1), 107-126. https://doi.org/10.1007/s10551-009-0143-8

Glavas, A. (2012). Employee Engagement and Sustainability: A Model for Implementing Meaningfulness at and in Work. Journal of Corporate Citizenship, 2012(46), 13-29. https://doi.org/10.9774/GLEAF.4700.2012.su.00003

Glavas, A. (2016). Corporate Social Responsibility and Employee Engagement: Enabling employees to employ more of their whole selves at work. Frontier in Psychology, 7(796), 1-10. https://doi.org/10.3389/fpsyg.2016.00796

Glavas, A., \& Kelley, K. (2014). The effects of perceived corporate social responsibility on employees. Business Ethics Quarterly, 24, 165-202. https://doi.org/10.5840/beq20143206

Glavas, A., \& Piderit, S. K. (2009). How Does Doing Good Matter? Effects of Corporate Citizenship on Employees. Journal of Corporate Citizenship, 36, 51-70. https://doi.org/10.9774/GLEAF.4700.2009.wi.00007

Guerci, M., Radaelli, G., Siletti, E., Cirella, S., \& Rami, S. A. B. (2015). The impact of human resource management practices and corporate sustainability on organizational ethical climates: An employee perspective. Journal of Business Ethics, 126, 325- 342. https://doi.org/10.1007/s10551-013-1946-1

Guest, D. E. (2011). Human resource management and performance, still searching for some answers. Human Resource Management Journal, 2(1), 3-13. https://doi.org/10.1111/j.1748-8583.2010.00164.x

Gunkel, M., Lusk, E. J., \& Wolff, B. (2009). Country-compatible incentive design. Schmalenbach Business Review, 61(3), 290-309. https://doi.org/10.1007/BF03396788

Gunnigle, P., Heraty, N., \& Morley, M. J. (2011). Human Resource Management in Ireland. Dublin, Ireland: Gill and MacMillan.

Hall, E. S. (2014). Onboarding to improve library retention and productivity. The Bottom Line, 27(4), 138-141. https://doi.org/10.1108/BL-10-2014-0026

Harter, J. K., Schmidt, F. L., \& Hayes, T. L. (2002). Business-unit level relationship between employee satisfaction, employee engagement, and business outcomes: A meta-analysis. Journal of Applied Psychology, 87(2), 268-279. https://doi.org/10.1037/0021-9010.87.2.268

Harter, J. K., Schmidt, F. L., Agrawal, S., Plowman, S. K., \& Blue, A. (2016). The relationship between engagement at work and organizational outcomes 2016 Q12® Meta-Analysis: Ninth Edition. Retrieved from http://www.workcompprofessionals.com/advisory/2016L5/august/MetaAnalysis_Q12_Resear chPaper_0416_v5_sz.pdf

Hayes, A. F. (2013). Introduction to Mediation, Moderation, and Conditional Process Analysis: A Regression-Based Approach. New York, NY: The Guilford Press.

Hodgson, G. (2013). On the limits of Rational Choice Theory. Economic Thought, 1(1), 94-108.

Holbeche, L., \& Springett, N. (2003). In search of meaning in the workplace. Horsham, UK: Roffey Park. 
Homans, G. C. (1958). Social behavior as exchange. American Journal of Sociology, 63(6), 597-606. https://doi.org/10.1086/222355

Hong, E. N. C., Hao, L. Z., Kumar, R., Ramedran, C., \& Kadiresan, V. (2012). An effectiveness of human resource management practices on employee retention in higher learning: A regression analysis. International Journal of Business Research and Management, 3(2), $60-79$.

Huselid, M. A. (1995). The impact of human resource practices on turnover, productivity, and corporate financial performance. Academy of Management Journal, 38(3), 635-672. https://doi.org/10.2307/256741

Ijigu, A. W. (2015). 'The effect of selected human resource management practices on employees' job satisfaction in Ethiopian public banks'. Emerging Markets Journal, 5(1), 1-16. https://doi.org/10.5195/EMAJ.2015.64

Jackson, J. D., Mun, Y. Y., \& Park, J. S. (2013). An empirical test of three mediation models for the relationship between personal innovativeness and user acceptance of technology. Information and Management, 50(4), 154-161. https://doi.org/10.1016/j.im.2013.02.006

Jansen, E., \& Von Glinow, M. A. (1985). Ethical Ambivalence and Organizational Reward Systems. Academy of Management Review, 10(4), 814-822.

Jaramillo, F., Mulki, J. P., \& Boles, J. S. (2013). Bringing meaning to the sales job: The effect of ethical climate and customer demandingness. Journal of Business Research, 2301-2307. https://doi.org/10.1016/j.jbusres.2012.03.013

Jaramillo, F., Mulki, J. P., \& Solomon, P. (2006). The role of ethical climate on salesperson's role stress, job attitudes, turnover intention, and job performance. Journal of Personal Selling Sales Management, 26, 271-282. https://doi.org/10.2753/PSS0885-3134260302

Jones, D. A. (2010). Does serving the community also serve the company? Using organizational identification and social exchange theories to understand employee responses to a volunteerism program. Journal of Occupational and Organizational Psychology, 83, 857-878. https://doi.org/10.1348/096317909X477495

Kahn, W. A. (1990). Psychological conditions of personal engagement and disengagement at work. Academy of Management Journal, 33(4), 692-724. https://doi.org/10.2307/256287

Kao, S., Ho, M., Wu, C., \& Lee, T. (2009). Relationships between employees' perception of corporate social responsibility, personality, job satisfaction, and organizational commitment. Retrieved from http://bai2009.org/file/Papers/1224.doc

Khilji, S. E., \& Wang, X. (2006). "Intended" and implemented" HRM: The missing linchpin in strategic human resource management research. The International Journal of Human Resource Management, 17, 1171-1189. https://doi.org/10.1080/09585190600756384

Kominis, G., \& Emmanuel, C. (2005). "Exploring the reward preferences for middle managers." Qualitative Research in Accounting Management, 2(1), 54-76. https://doi.org/10.1108/11766090510635389

Kooij, T. A. M., Jansen, P. G. W., Dikkers, J. S. E., \& De Lange, A. H. (2010). The influence of age on the associations between HR practices and both affective commitment and job satisfaction. Journal of Organizational Behavior, 31, 1111-1136. https://doi.org/10.1002/job.666 
Kuvaas, B. (2008). An exploration of how the employee-organization relationship affects the linkage between perception of developmental human resource practices and employee outcome. Journal of Management Studies, 45, 1-25.

Lawler, E. I. (2003). Reward practices and performance management symtem effectiveness. Organizational Dynamics, 32(4), 96. https://doi.org/10.1016/j.orgdyn.2003.08.007

Lee, M., \& Kim, W. (2015). The effect of perceived corporate social responsibility on hotel employees's attitute and behaviour toward the organization. International Journal of Tourism Science, 13, 51-74. https://doi.org/10.1080/15980634.2013.11434680

Lepak, D. P., Takeuchi, R., \& Snell, S. A. (2003). Employment flexibility and firm performance: Examining the interaction effects of employment mode, environmental dynamism, and technogical intensity. Journal of Management, 29, 681-703. https://doi.org/10.1016/S0149-2063(03)00031-X

Lockwood, N. R. (2007). Leveraging Employee Engagement. SHRM Research Quarterly, 52(3), 1-12.

Macey, W. H., \& Schneider, B. (2008). The meaning of employee engagement. Industrial and Organizational Psychology, 1(1), 3-30. https://doi.org/10.1111/j.1754-9434.2007.0002.x

Mann, A., \& Harter, J. (2016). The worldwide employee engagement crisis. Retrieved December 5, 2017, from http://gallup.com/businessjournal/188033/worldwide-emploee-engagementcrisis.aspx

Mantroop, L., Singh, P., \& Ezzedeen, S. (2014). Human Resource Systems and Ethical Climates: A Resource Based Perspective. Human Resource Management, 53(5), 795-816. https://doi.org/10.1002/hrm.21593

Markos, S., \& Sridevi, M. S. (2010). Employee Engagement: The key to improving performance. International Journal of Business and Management, 5(12), 89-96.

Martin, K. D., \& Cullen, J. B. (2006). Continuities and extensions of ethical climate theory: A meta-analytic review. Journal of Business Ethics, 69(2), 175-194. https://doi.org/10.1007/s10551-006-9084-7

Maslach, C., Schaufeli, W. B., \& Leiter, M. P. (2001). Job Burnout. Annual Review of Psychology, 52, 397-422. https://doi.org/10.1146/annurev.psych.52.1.397

Matiaske, W. (2004). Pourquoi pas? Rational choice as a basic theory of HRM. Management Review, 15(2), 249-263.

Mayer, D., Kuenzi, M., \& Greenbaum, R. (2010). Examining the link between ethical leadership and employee misconduct: The mediating role of ethical climate. Journal of Business Ethics, 95(1), 7-16. Journal of Business Ethics, 95(1), 7-16. https://doi.org/10.1007/s10551-011-0794-0

Mehmood, T., Qasim, S., \& Azam, R. (2013). Impact of emotional intelligence on the performance of university teachers. Journal of Humanities and Social Science, 3(18), 300-307.

Miller, J. (2017). Employees Spend 1 Percent of Their Week on Training. Make it Count. Retrieved from https://www.inc.com/jeff-miller/us-companies-spend-70-billion-on-training-a-year-heres-how 
-to-make-your-investment-worthwhile.html.

Mohrman, S. A., \& Shani, A. B. (2011). Organizing for sustainability. Bingley: Emerald Group Publishing. https://doi.org/10.1108/S2045-0605(2011)1

Mone, E. M., \& London, M. (2010). Employee Engagement through Effective Performance Management: A practical guide for managers. Routledge.

Nishii, L. H., \& Wright, P. (2008). Variability within organizations. In D. B. Smith (Ed.), The people make the place: Dynamic linkages between individuals and organizations. (pp. 225-248). New York: Lawrence Erlbaum Associates.

Nishii, L. H., Lepak, D. P., \& Schneider, B. (2008). Employee attributions of the "why" of HR Practices: Their effects on employee attitutes and behaviours, and customer satisfaction. Personnel Psychology, 61, 503-545. https://doi.org/10.1111/j.1744-6570.2008.00121.x

Parboteeah, K. P., Chen, H. C., \& Lin, Y. T. (2010). Establishing organizational ethical climates: How do managerial practices work? Journal of Business Ethics, 97, 599. https://doi.org/10.1007/s10551-010-0527-9

Parboteeaha, K. P., Serikib, H. T., \& Hoeglc, M. (2014). Ethnic diversity, corruption and ethical climates in sub-Saharan Africa: Recognizing the significance of human resource management. The International Journal of Human Resource Management, 25(7), 979-1001. https://doi.org/10.1080/09585192.2013.815251

Pfeffer, J. (1998). Seven practices of successful organizations. California Management Review, 40(2), 96-124. https://doi.org/10.2307/41165935

Piening, E. P., Baluch, A. M., \& Ridder, H. G. (2014). Mind the Intended and Implemented Gap: Understanding Employees' Perceptions of HRM. Human Resource Management, 53(4), 545-567. https://doi.org/10.1002/hrm.21605

Pitt, C. M., \& Matz, C. C. (2008). The multi-generational workforce: Workplace flexibility and engagement. Community, Work \& Family Journal, 11(2), 215-229. https://doi.org/10.1080/13668800802021906

Podsakoff, N. P., Whiting, S. W., Podsakoff, P. M., \& Blume, B. D. (2009). Individual and organizational-level consequences of organizational citizenship behaviors: A metaanalysis. Journal of Applied Psychology, 94(1), 122-141. https://doi.org/10.1037/a0013079

Qureshi, T. M., Marwat, Z. A., \& Ramay, M. I. (2007). Impact of Human Resource Management (HRM) Practices on Employees Performance: A Case of Pakistan Telecom Sector. Islamabad, Pakistan: MA Jinnah University-Department of Business Administration and Social Sciences.

Rich, B. L., Lepine, J. A., \& Crawford, E. R. (2010). Job engagement: Antecedents and effects on job performance. Academy of Management Journal, 53(3), 617-635. https://doi.org/10.5465/AMJ.2010.51468988

Rigg, J. (2013). Worthwhile concept or old wine? A review of employee engagement and related constructs. American Journal of Business and Management, 2(1), 31-36. https://doi.org/10.11634/216796061302229

Rigg, J. S. (2012). Are employees engaged? Drivers of hotel employees' work engagement, job satisfaction, and intention to quit. Purdue University. Retrieved from 
http://www.purdue.edu/policies/pages/teach_res_outreach/c_22.html

Rigoni, B., \& Nelson, B. (2016). Millennial Employees: Flight risk for companies. Retrieved February 3, 2018, from http://news.gallup.com/businessjournal/194810/millennials-flight-risk-companies.aspx

Rosso, B. D., Dekas, K. H., \& Wrzesniewski, A. (2010). 'On the Meaning of Work: A Theoretical Integration and Review'. Research in Organizational Behaviour, 30, 91-127. https://doi.org/10.1016/j.riob.2010.09.001

Rowland, C., \& Hall, R. (2014). Management learning, performance and reward: theory and practice revisited'. Journal of Management Development, 33(4), 342-356. https://doi.org/10.1108/JMD-08-2012-0110

Rupp, D. E., \& Mallory, D. B. (2015). Corporate Social Responsibility: Psychological, Person-Centric, and Progressing. Annual Review of Organizational Psychology and Organizational Behaviour, 2(1), 211-236. https://doi.org/10.1146/annurev-orgpsych-032414-111505

Rupp, D. E., Shao, R., Thornton, M. A., \& Skarlicki, D. P. (2013). Applicants' and employees' reactions to Corporate Social Responsibility: The moderating effects of first-party justice perceptions and moral identity. Personnel Psychology, 66(4), 895-933. https://doi.org/10.1111/peps.12030

Rupp, D. E., Williams, C. A., \& Aguilera, R. V. (2010). Increasing corporate social responsibility through stakeholder value internalization and the catalyzing effect of new governance : An application of organizational justice, self-determination, and social influence theories. In M. Schminke (Ed.), Managerial ethics: Managing the psychology of morality (pp. 69-88). New York: Routledge.

Saks, A. M. (2006). Antecedents and consequences of employee engagement. Journal of Managerial Psychology, 21(7), 600-619. https://doi.org/10.1108/02683940610690169

Saks, A. M., \& Gruman, J. A. (2014). What do we really know about employee engagement? Human Resource Development Quarterly, 25(2), 155-182. https://doi.org/10.1002/hrdq.21187

Schaufeli, W. B. (2014). What is engagement? In C. Truss, K. Alfes, R. Delbridge, A. Shantz, $\&$ E. Soane (Eds.), Employee Engagement in Theory and Practice (pp. 15-35). Routledge.

Schaufeli, W. B., Salanova, M., Gonzalez, R. V., \& Bakker, A. B. (2002). The measurement of engagement and burnout: A two sample confirmatory factor analytic approach. Journal of Happiness Studies, 3(10), 71-92. https://doi.org/10.1023/A:1015630930326

Schminke, M., Ambrose, M. L., \& Neubaum, D. O. (2005). The effect of leader moral development on ethical climate and employee attitudes. Organizational Behaviour and Human Decision Processes, 97(2), 135-151. https://doi.org/10.1016/j.obhdp.2005.03.006

Schneider, B., Gunnarson, S., \& Niles, J. K. (1994). Creating the climate and culture of success. Organizational Dynamics, 23(1), 17-29. https://doi.org/10.1016/0090-2616(94)90085-X

Schwepker, C. H. (2001). Ethical climate's relationship to job satisfaction, organizational commitment, and turnover intention in the sales forces. Journal of Business Research, 54(1), 39-52. https://doi.org/10.1016/S0148-2963(00)00125-9

Sekerka, L. E. (2009). Organizational ethics education and training: A review of best practices 
and their application. International Journal of Training and Development, 13(2), 77-95. https://doi.org/10.1111/j.1468-2419.2009.00319.x

Shen, J., \& Benson, J. (2014). When CSR is social norm: How socially responsible human resource management affects work behaviour. Journal of Management, 40, 1-24.

Shin, Y. (2012). CEO ethical leadership, ethical climate, climate strength, and collective organizational citizenship behavior. Journal of Business Ethics, 108(3), 299-312. https://doi.org/10.1007/s10551-011-1091-7

Shuck, B., Reio, J. T. G., \& Rocco, T. S. (2011). Employee engagement: An examination of antecedent and outcome variables. Human Resource Development International, 14(4), 427-445. https://doi.org/10.1080/13678868.2011.601587

Simha, A., \& Cullen, J. B. (2012). Ethical climates and their effects on organizational outcomes: Implications from the past and prophecies for the future. Academy of Management Perspectives, 6(4), 20-34. https://doi.org/10.5465/amp.2011.0156

Simon, G., \& Zhou, I. (2017). Harmonizing modern day Employee Engagement with the sociological theory of Symbolic Interactionism. American Journal of Business and Management, 6(2), 52-59.

Simpson, M. R. (2009). Engagement at work: A review of the literature. International Journal of Nursing Studies, 46, 1012-1024. https://doi.org/10.1016/j.ijnurstu.2008.05.003

Singh, K. (2004). Impact of HR practices on perceived firm performance in India. Asia Pacific Journal of Human Resources, 42(3), 301-317. https://doi.org/10.1177/1038411104048170

Sorenson, S. (2013). How employee engagement drives growth. Gallup Business Journal, 1, $1-4$.

Sparrow, P. (2014). Strategic HRM and employee engagement. In C. Truss, K. Alfes, A. Shantz, $\&$ E. Soane (Eds.), Employee engagement in theory and practice. Oxon, UK: Routledge.

Stewart, R., Volpone, S. D., Avery, D. R., \& Mckay, P. (2011). You support diversity, but are you ethical? Examining the interactive effects of diversity and ethical climate perceptions on turnover intentions. Journal of Business Ethics, 100(4), 581-593. https://doi.org/10.1007/s10551-010-0697-5

Tangthong, S., Trimetsoontorn, J., \& Rojniruntikul, N. (2014). HRM Practices and Employee Retention in Thailand - A Literature Review. International Journal of Trade, Economics and Finance, 5(2), 162-166. https://doi.org/10.7763/IJTEF.2014.V5.362

Taylor, J., \& Taylor, R. (2011). Working Hard for More Money or Working Hard to Make a Difference? Efficiency Wages, Public Service Motivation, and Effort. Review of Public Personnel Administration, 31(1), 67-86. https://doi.org/10.1177/0734371X10394401

Thang, N. N., \& Buyens, D. (2008). What we know about relationship between training and firm performance: A review of literature. Presented at the 7th International Conference on Ethics and Quality of Work-life for Sustainable Development, Bangkok, Thailand.

Thite, M. (2013). Ethics and human resource management and development in a global context: case study of an Indian multinational. Human Resource Development International, 16(1), 106-115. https://doi.org/10.1080/13678868.2012.737691

Training Magazine. (2016, December). Future Focus. Retrieved from 
https://trainingmag.com/sites/default/files/images/Training_Industry_Report_2016.pdf

Truss, C., Alfes, K., Delbridge, R., Shantz, A., \& Soane, E. (2013). Employee Engagement in Theory and Practice. Routledge.

Truss, C., Soane, E., Edwards, C., Wisdom, K., Croll, A., \& Burnett, J. (2006). Working Life: Employee Attitudes and Engagement. Wimbledon: CIPD.

Victor, B., \& Cullen, J. B. (1987). A theory and measure of ethical climate in organizations. Research in Corporate Social Performance and Policy, 9, 51-71.

Vuuren, L. J. V., \& Eiselen, R. J. (2006). A role for HR in corporate ethics? South African practitioners' perspectives. South African Journal of Human Resource Management, 4(3), 22-28. https://doi.org/10.4102/sajhrm.v4i3.95

Wagner, R. (2015). The end of employee engagement? Forbes Magazine. Retrieved from https://www.forbes.com/sites/roddwagner/2015/05/11/the-end-of-employee-engagement/.

Way, S. S., \& Johnson, D. E. (2005). Theorizing about the impact of strategic human resource management. Human Resource Management, 15(1), 1-19. https://doi.org/10.1016/j.hrmr.2005.01.004

Whittingham, J. L., \& Galpin, T. J. (2010). The engagement factor: Building high-commitment organizations in a low-commitment world. Journal of Business Strategy, 31(5), 14-24. https://doi.org/10.1108/02756661011076282

Wollard, K. K., \& Shuck, B. (2011). Antecedents to employee engagement: A structured review of the literature. Advances in Developing Human Resources, 13(4), 429-446. https://doi.org/10.1177/1523422311431220

Wright, P. M., \& Nishii, L. H. (2007). Strategic HRM and organizational behavior: Integrating multiple levels of analysis. CAHRS Working Paper Series, 468.

Wright, P. M., \& Nishii, L. H. (2010). Strategic HRM and Organizational Behaviour: Integrating multiple levels of analysis. In D. E. Guest, J. Paauwe, \& P. M. Wright (Eds.), Human Resource Management and Performance: Progress and Prospects. Oxford, UK: Blackwell Publishing Ltd.

Wrzesniewski, A., Cameron, S., Dutton, J. E., \& Quinn, R. E. (2003). Finding Positive Meaning in Work. In Positive organizational scholarship: Foundations of a new discipline (pp. 296-308). San Francisco: Berrett-Koehler.

Zhang, B., \& Morris, J. L. (2014). High -performance work systems and organizational performance : Testing the mediation role of employee outcomes using evidence from PR China. The International Journal of Human Resource Management, 25, 68-90. https://doi.org/10.1080/09585192.2013.781524 


\section{Appendices}

Appendix 1. Survey questionnaire

\section{EMPLOYEE ENGAGEMENT QUESTIONNAIRE}

Please read each statement carefully and decide on the answer that best describes your honest opinion.

On the scale of 1 to 5, please SELECT that best answer that best represents your level of agreement or disagreement with the each question.

$($ Strongly disagree $=1$, Disagree $=2$, Neutral $=3$, Agree $=4$ and Strongly agree $=5$ )

\section{SECTION 1: HRM PRACTICES}

The following statements are about how you feel about the HRM practices in your organization.

\section{Reward and compensation practice}

1. The reward management practice in this $1 \quad 2 \quad 35$ organization is fair.

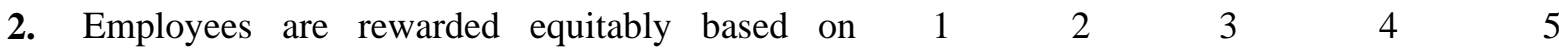
performance.

3. I am satisfied with my overall compensation. $\quad \begin{array}{llllll}1 & 2 & 3 & 4\end{array}$

\section{Training and development practice}

4. There is a commitment to on-going training and $\begin{array}{llllll}1 & 2 & 3 & 4 & 5\end{array}$ development of employees.

5. There are many opportunities to learn and grow both personally and professionally.

6. I am satisfied that I have the ability to utilize my $\begin{array}{lllllll}1 & 2 & 3 & 4 & 5\end{array}$ talents and expertise on the job.

\section{SECTION 2: ORGANIZATIONAL ETHICAL CLIMATE}

In this section, please think about the workplace climate in your organization and the extent to which you agree or disagree with each of the items.

7. People are expected to do anything to further the $\quad \begin{array}{llllll}1 & 2 & 3 & 4 & 5\end{array}$ company's interests.

8. People are concerned with the company's interests $\quad \begin{array}{llllll}1 & 2 & 3 & 4 & 5\end{array}$ - to the exclusion of all else.

9. It is very important to follow strictly the

$\begin{array}{lllll}1 & 2 & 3 & 4 & 5\end{array}$
company's rules and procedures here.

10. Successful people in this company strictly obey $\quad \begin{array}{llllll}1 & 2 & 3 & 4\end{array}$ company policies. 
11. I am aware of sustainability agenda in terms of 1 2 3 4 5 Management attention and investment in my company

12. Your organization's sustainability agenda influence you to exert extra effort and engage in behaviours that contribute to your organizations success.

13. Your organization's practices and policies are influenced by sustainability.

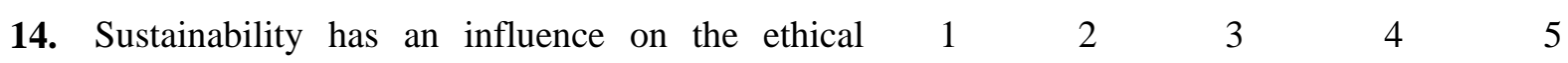
climate of your organization

\section{SECTION 4: EMPLOYEE ENGAGEMENT}

We are interested in the relationship between the organizational climate and its relatedness to your level of engagement across the organization. Please use the scale below to express your feeling about work and the organization.

15. I know what is expected of me at work.

12

3

$4 \quad 5$

16. I have the materials and equipment I need to do 12 3 my work right.

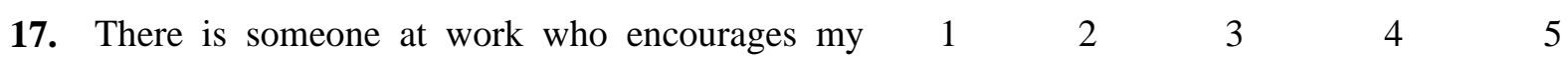
development.

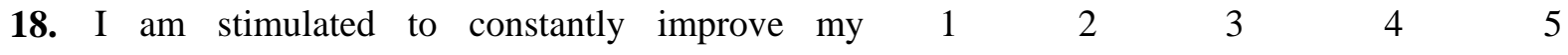
performance.

19. Considering everything, you would say that you $\quad \begin{array}{llllll}1 & 2 & 3 & 4 & 5\end{array}$ are satisfied in your job and the organization

\section{SECTION 5: DEMOGRAPHIC AND ORGANIZATIONAL CHARACTERISTS}

This last set of questions is important to give us a sense of who completed the questionnaire. No attempt will be made to identify individual respondents.

20. Are you a manager?

Yes No

21. Sex

Male Female

22. Age range $20-29 \quad 30-35 \quad 36-40$ $41-49$ 50 or older 
Appendix 2. Descriptive statistic on the respondents' response to items on HRMPs (R\&C and T\&C), OEC, CS, and EE.

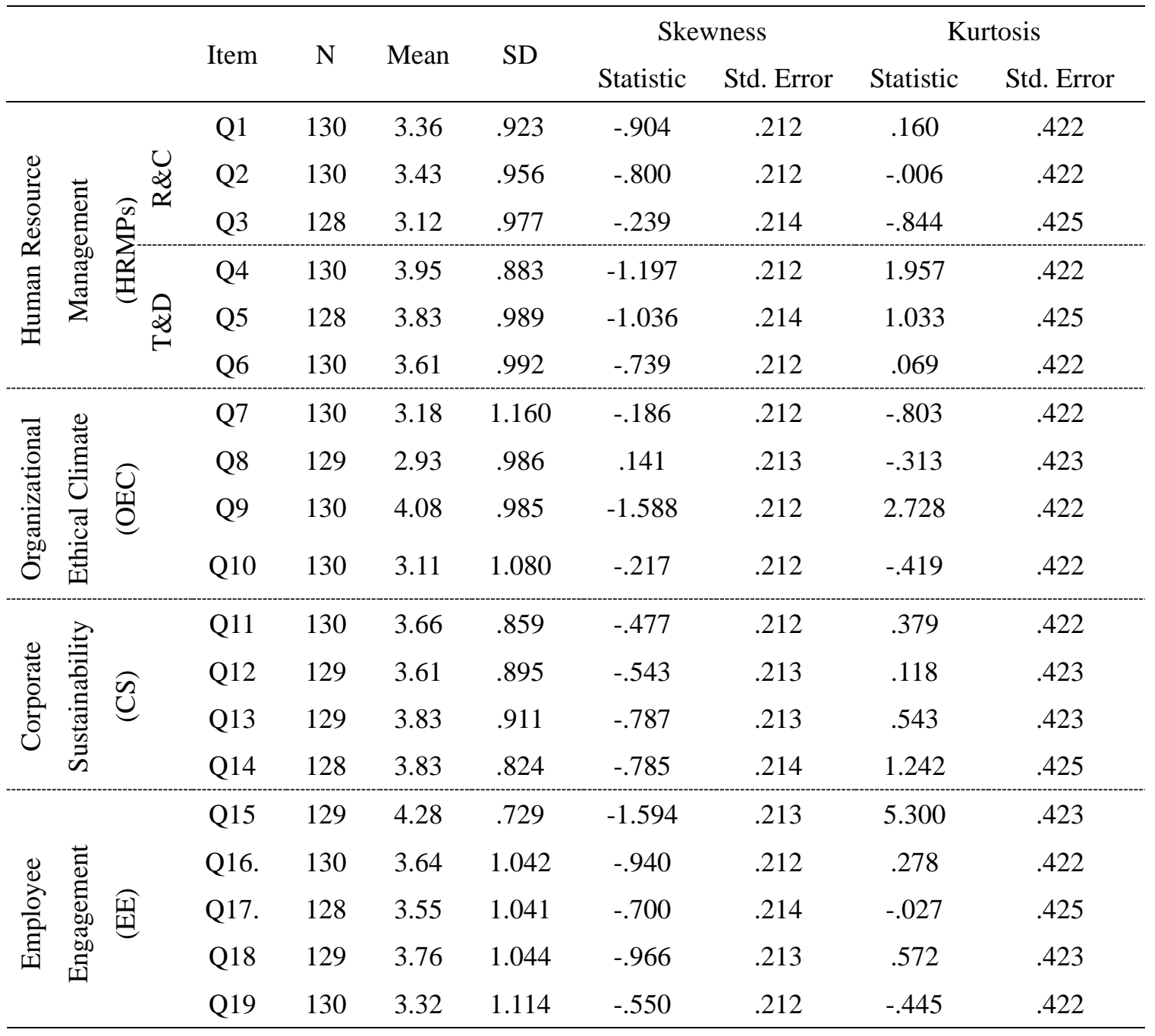


Appendix 3. T-test and ANOVA of relationship between respondents' demography and organizational characteristics, and employee engagement.

\begin{tabular}{|c|c|c|c|c|c|c|}
\hline Variable & & Mean & SD & $T$ & $F$ & $p$ \\
\hline \multirow[t]{2}{*}{ Gender } & Male & 3.78 & .80 & -1.547 & & .124 \\
\hline & Female & 3.50 & .88 & & & \\
\hline \multirow[t]{5}{*}{ Age } & $20-29$ & 3.70 & .99 & & 1.464 & .217 \\
\hline & $30-35$ & 3.34 & 1.00 & & & \\
\hline & $36-40$ & 3.41 & .60 & & & \\
\hline & $41-49$ & 3.67 & .81 & & & \\
\hline & $\geq 50$ & 3.90 & .57 & & & \\
\hline \multirow{5}{*}{$\begin{array}{l}\text { Level of } \\
\text { education }\end{array}$} & Diploma & 3.72 & .74 & & .324 & .808 \\
\hline & Bachelors & 3.53 & .88 & & & \\
\hline & Masters & 3.47 & .83 & & & \\
\hline & $\mathrm{PhD}$ & - & - & & & \\
\hline & Other & 3.63 & 1.00 & & & \\
\hline \multirow[t]{2}{*}{ Level } & Manager & 3.70 & 1.03 & -.653 & & .515 \\
\hline & Non-manager & 3.54 & .84 & & & \\
\hline \multirow[t]{5}{*}{ Department } & Retail/sales & 3.55 & .80 & & .866 & .487 \\
\hline & $\begin{array}{l}\text { Customer } \\
\text { service }\end{array}$ & 3.56 & 1.01 & & & \\
\hline & Operations & 3.30 & 1.09 & & & \\
\hline & Administration & 3.45 & .59 & & & \\
\hline & Head office & 3.82 & .76 & & & \\
\hline \multirow{4}{*}{$\begin{array}{l}\text { Length of } \\
\text { service }\end{array}$} & $<1$ year & 4.11 & .40 & & 2.833 & $.041^{*}$ \\
\hline & $1-5$ years & 3.55 & 1.01 & & & \\
\hline & $6-10$ years & 3.19 & .81 & & & \\
\hline & $\geq 11$ years & 3.60 & .81 & & & \\
\hline
\end{tabular}

Note: * Significant at $\mathrm{p}<0.05$

\section{Copyright Disclaimer}

Copyright for this article is retained by the author(s), with first publication rights granted to the journal.

This is an open-access article distributed under the terms and conditions of the Creative Commons Attribution license (http://creativecommons.org/licenses/by/4.0/). 